\title{
INTRODUCTION
}

Volume 12 of the Journal of Jungian Scholarly Studies (JJSS) introduces a grounding initiative: the inclusion of poems and visual art as forms of knowing that exist in conversation with the article form of scholarship. The proposal for this innovation emerged from reflection by members of the editorial board upon the presentations at the Jungian Society of Scholarly Studies' (JSSS) conference on the theme of Earth/Psyche held in Santa Fe, New Mexico, in 2016. The conference began with JSSS President Susan Rowland hosting an evening of poetry featuring the cosmology poems of Joel Weishaus and including poems written and read by a few attendees. During the body of the conference, a remarkable number of the speakers included either poems or visual art or both in their talks. To communicate their research concerning Earth's relations to psyche, presenters repeatedly turned to art to share their knowledge.

This volume harvests developed versions of eight of those presentations as articles and publishes them juxtaposed with poems and visual art selected by our journal's new poetry and art editors. The juxtaposition is intended to spark connections-conceptual, emotional, kinesthetic, and aesthetic - between the complex analyses offered in the articles and the levels of consciousness stirred by the art.

Perceiving such connections will affirm the overarching theme that the authors of the articles independently of one another claim as premise: the interconnectedness of being. In that spirit, I offer in this introduction a sample of points of connection between the articles. The topics of the articles address a range of subject matter: the impact of imagination, particularly the practice of active imagination, in transforming human consciousness and behavior, thus advancing planetary individuation; the synchronous relationships between body and earth in the healing modality of Biodynamic Craniosacral Therapy; the existence of a salt daemon working to increase harmonious relations between material, alchemical, and psychic levels of being; Christianity's evolving relations to Earth and reclaimed approaches to scripture that enable Christians to participate in divinized creation; the psyche of a specific place, Cornwall, England, and the psychic image of a place, Santa Fe, New Mexico, including the shadow aspects caused by colonization; and the possibility of utilizing the common characteristics of large-group identities to integrate difference so as to develop conscience enabling constructive political action. Themes that resonate with one another in the various articles include imagination, the psychoid, the feminine, the body, and transformation.

Not only is the present volume distinguished by the inclusion of poems and visual art; it also contains more narratives of personal experience than in the past. It has been the policy of JJSS only to publish personal experience if it supports a new idea, not merely illustrates an established one. That policy partially continues, but it turns out that examining the relations of Earth/Psyche has elicited the experiential in research in ways more numerous than illustration or support.

Personal experience as numinous encounter initiates Susan Courtney's discovery of the salt daemon and her subsequent research into parallels between physical salts, alchemical salts, and the psychoid nature of earth and psyche, research leading to her contributing to Jungian theory the idea of a salt daemon as an inherent movement of multi-faceted being toward bringing coherence to the ever unfolding series of incoherent 


\section{INTRODUCTION continued}

states. Personal experience as numinous dreams leading to an understanding of his calling to speak for the psyche of a place motivates Guy Dargert's exploration of the folklore and colonized history of the inhabitants of Cornwall and of the psychological dangers in the allurement of Cornwall's beguiling beauty. Personal experience as numinous dreams, but also as embodied practices of active imagination, animates Ciuin Doherty's call for collective understanding that all that exists, including each human being, is the current realization of over 13 billion years of the evolution of the universe. The ramifications of that understanding include reconceiving the import of individuation, recognizing that humans individuate not only for themselves, but also as expressions of planet Earth's individuating through them. Understanding the permeability of personal experience, its unconscious connections with other beings and the environment through synchronicities capable of being made conscious enough for healing to occur, is given life in Jane Shaw's article on the therapeutic power of Biodynamic Craniosacral Therapy.

Other authors refer to personal experience in more traditional ways. David Barton, in his article on the psychic image of Santa Fe, reports on experiencing the profound alterity of the Laguna Pueblo culture as he listened to Leslie Marmon Silko speak of rescuing a rattlesnake. Like Dargert, Barton acknowledges the shadow of centuries of colonization. He reports being told by young natives of their despairing sense of entrapment in New Mexico. Johnathan Erickson, concerned about negative attitudes toward Christianity's teachings about the Earth, shares that his efforts to underscore the vein in Christian teachings that counters the scripture about human dominance over nature are motivated by his being the son of a Christian minister and of a mother with pagan leanings. Peter Dunlap offers his experience as an illustration of the psychocultural work he is hoping Jungian clinicians will engage in to bring the healing power of psychological understanding to cultural dilemmas. And while Nanette Walsh does not share personal experience of her own, she calls on the scholarship concerning the personal experience of women in Jesus's time to argue for interpreting scripture in a way that divinizes the experience of female persons, a step toward knowing the divine in all creation. Writing about the psychological relations of Earth/Psyche apparently elicits the grounding of thought in personal experience, a grounding typically invisible in abstract scholarly communications.

Personal experience obviously is the ground for art. Our journal's call for visual art related to Earth/Psyche invited artists to submit commentary along with their work. Judging from the responses that we received, the artists whose work is published here experience artistic creation as transformation of matter with abstract implications: turning clay into a holding vessel like that of analysis (Kristine Anthis), turning chance happenings into a creation (Marilyn DeMario), turning disparate materials into an integrated piece (Diane Miller), turning reversals into continuity (S. Sowbel), turning visual metaphor into ensouling symbol (Heather Taylor-Zimmerman), and turning the relation of abstract numbers/concrete matter into paintings echoing the composition of our world (Lucia Grossberger-Morales).

The poems on the theme of Earth/Psyche selected for this volume reflect the distinguishing power of individuation in their range of subject and style. Margaret 


\section{INTRODUCTION continued}

Blanchard's poems address the changing nature of the poet's relation to the Earth over time; Judith Capurso's not only challenge human assertion of dominance over the Earth, but also liberate people from the inflation of that dominance; Ursula Shields-Huemer's haiku grace imaginings of the natural word through presence; Brown Dove's poem juxtaposes shifting evaluations of idols and continuity of Earth's rhythms; and S. Sowbel's focuses attention on what does not get reborn in her rendering of generativity.

Certain concepts are explored in more than one of the articles which suggests their inherent significance in considering the relations of Earth/Psyche. In particular, Jung's relatively neglected concept of the psychoid receives thoughtful elaboration, especially in the articles by Courtney and Shaw. Shaw applies the concept in her explanation of the healing power of the Biodynamic Craniosacral Therapy treatment (BCST). Courtney provides scientific data connecting rhythms of the body to the environment. Shaw's account of the intelligence of the body during the giving and receiving of a BCST treatment resonates with Courtney's account of electrolytic solution and of rhythmic entrainment. Doherty also contributes to reevaluating the body in terms of its knowingness through his exploration of the perspective of right-brain knowing. The theme of the body's intelligence flows directly from the premise of interconnectedness attributing psyche to Earth.

Another thread through the articles concerns the way the interconnectedness of being is conceived. Courtney references Jung's concept or Eros as well as British anthropologist Timothy Ingold's conception of humans as a "'relational constitution of being' enmeshed in a planetary 'domain of entanglement' of 'interlaced lines of relationship." Doherty connects Eckhart's description of the divine as emptiness with the quantum physics description of the emergence and disappearance of elementary particles from and into nothingness to assert that creative intelligence is inherent in all being. Dargert proposes that places are infused with their own form of psyche through the existence of an enveloping continuum. Dunlap points to Jung's idea of a superconsciousness in the unconscious. The authors writing about religion, Erickson and Walsh, see God as the source of being's interconnectedness. Erickson traces the evolution in Western Christianity of an understanding that the Earth as God's creation deserves care, an understanding receiving recent expression in Pope Francis's Laudato Si': On Care for our Common Home. Walsh through the concept of practical divinization attempts to rectify the omission of ecology, women, and psychology in traditional Christian practice of divinization. She links aspects of the historical lineage of the idea of person and Jung's articulation of individuation to argue for knowing divine wisdom in all that exists.

Most of the authors assert that integration of the feminine is key to addressing ecological crises, often specifying that by the feminine they are referring to Eros. Walsh, however, argues for redefining what the feminine is in terms of women's experience and for using women's imaginative works to understand the feminine. For example, she cites Annis Pratt who, after surveying over 300 novels written by women, concludes that transformation for women occurs through the "green epiphany," that is, through their relationship with nature. Walsh's article provides a significant counterpoint to 


\section{INTRODUCTION continued}

traditional Jungian understanding of the feminine and of what it would mean to integrate it for the purpose of addressing our ecological crises.

Finally, Peter Dunlap's article grapples with how to bring Jung's understanding of the collective unconscious to a psychocultural practice of confronting the capacity of large groups to degenerate into mass-mindedness. He argues for confronting that tendency by consciously applying techniques to help large groups develop a sense of shared identity capable of integrating difference, thus making possible development of conscience about relations to the rest of the world. His article shares recent social science research about how to attempt that process, including an illustration of his own experience of applying some of those techniques. His essay gestures toward the goal of bringing psychological knowledge into civic life to enable constructive political action, a goal implicit in the conference on the relations of Earth/Psyche and in this volume of $J J S S$ issuing from it.

Inez Martinez

Editor 